\title{
Camellia sinensis (L.) Kuntze Extract Ameliorates Chronic Ethanol-Induced Hepatotoxicity in Albino Rats
}

\author{
Poonam Lodhi, ${ }^{1}$ Neeraj Tandan, ${ }^{2}$ Neera Singh, ${ }^{1}$ Divyansh Kumar, ${ }^{3}$ and Monu Kumar ${ }^{2}$ \\ ${ }^{1}$ Environmental Endocrinology and Biomedical Research Unit, Department of Zoology, Meerut College, Meerut 250003, India \\ ${ }^{2}$ Scientific and Applied Research Center, Meerut 250001, India \\ ${ }^{3}$ D.A.V. (P.G.) College, Bulandshahr 203001, India
}

Correspondence should be addressed to Poonam Lodhi; poonamlodhi@gmail.com

Received 25 April 2014; Revised 4 June 2014; Accepted 9 June 2014; Published 31 August 2014

Academic Editor: Ravirajsinh Jadeja

Copyright (C) 2014 Poonam Lodhi et al. This is an open access article distributed under the Creative Commons Attribution License, which permits unrestricted use, distribution, and reproduction in any medium, provided the original work is properly cited.

\begin{abstract}
The goal of this study was to investigate the hepatoprotective effects of aqueous extract of Camellia sinensis or green tea extract (AQGTE) in chronic ethanol-induced albino rats. All animals were divided into 4 groups in the study for a 5-week duration. $50 \%$ ethanol was given orally to the rats with two doses $(5 \mathrm{mg} / \mathrm{kg} \mathrm{bw}$ and $10 \mathrm{mg} / \mathrm{kg} \mathrm{bw})$ of AQGTE. Ethanol administration caused a significant increase in the levels of plasma and serum enzymatic markers, alanine aminotransferase (ALT), aspartate aminotransferase (AST), and alkaline phosphatase (ALP), and nonenzymatic markers (cholesterol and triglycerides), lipid peroxidation contents, malondialdehyde (MDA), and glutathione-S-transferase (GST), and decreased the activities of total proteins, albumin, and cellular antioxidant defense enzymes such as superoxide dismutase (SOD). The elevation and reduction in these biochemical enzymes caused the damage in hepatocytes histologically due to the high production of ROS, which retards the antioxidant defense capacity of cell. AQGTE was capable of recovering the level of these markers and the damaged hepatocytes to their normal structures. These results support the suggestion that AQGTE was able to enhance hepatoprotective and antioxidant effects in vivo against ethanol-induced toxicity.
\end{abstract}

\section{Introduction}

Alcohol is widely consumed in alcoholic drinks in modern society, and ethanol is one of the main causes of a variety of medical problems and liver diseases worldwide [1]. The liver is the major target organ of ethanol toxicity [2]. Chronic ethanol feeding causes a decrease in the major antioxidant factors in the liver, including enzymes $[3,4]$ and nonenzymatic antioxidants $[5,6]$. This is due to the generation of an excessive amount of reactive oxygen species (ROS), which results in the detrimental effects of the cellular antioxidant defense system $[7,8]$. Thus, excess alcohol consumption may accelerate an oxidative mechanism directly or indirectly, which eventually produces cell death and tissue damage [913]. Therefore, alternative treatments for liver disorders are needed to replace the existing synthetic drugs.

The plants having antioxidants prevent the cell death and tissue damage resulting from chronic alcohol consumption [14].
Green tea (Camellia sinensis, Theaceae) is the second most popular beverage worldwide [15]. It contains six primary catechins or polyphenol compounds. These constituents have potent antioxidant action and their putative disease preventive effects [16]. These polyphenols prevent oxygen-free radicals-induced hepatocyte lethality, reduce the risk of liver disease, and protect against liver injury, that is, fibrosis and liver cirrhosis in rats [17-19]. In the current study, we evaluated the influence of green tea extract on liver specific enzymatic and nonenzymatic markers, lipid peroxidation, antioxidants in blood, and liver histology associated with chronic ethanol consumption.

\section{Materials and Methods}

2.1. Chemicals. Ethanol (purity (GC) $\geq 99.9 \%$ ) and all other chemicals were from Merck (Merck KGaA, Darmstadt, Germany). All chemicals used were of analytical grade. 
2.2. Animal Treatment. Twenty-four healthy male Wistar strain rats (100-140 g; 14-16 weeks old) were obtained from animal house of C.C.S, University, Meerut, U.P., India. All animals were acclimatized for laboratory conditions at room temperature and kept on normal diet. The tap water ad libitum was also provided for two weeks before starting the experiment. All animals were cared for according to guidelines of the Institutional Animal Ethics registered by IAEC (384/PO/a/01/CPCSEA 27-03-2015). Committee (IAEC) and experiments were also approved. The experiment duration was 5 weeks. All animals were divided into 4 groups: controls (received distilled water as drinking source), ethanol control ( $0.5 \mathrm{~mL} \mathrm{C}_{2} \mathrm{H}_{5} \mathrm{OH} / 100$ gm body weight), ethanol + GTE ( $0.5 \mathrm{~mL} \mathrm{C}_{2} \mathrm{H}_{5} \mathrm{OH}+5 \mathrm{mg}$ GTE/100 gm body weight), and ethanol + GTE $(0.5 \mathrm{~mL} \mathrm{C} 2 \mathrm{H} 5 \mathrm{OH}+10 \mathrm{mg}$ GTE/100 gm body weight). The animals of alcohol control group were administered oral dose of ethanol everyday between 10:00 AM and 11:00 AM. Experimental animals of group 3 and group 4 were given orally $5 \mathrm{mg}$ and $10 \mathrm{mg} / 100 \mathrm{gm}$ body weight dose of GTE, respectively, after 1 hour of feeding of alcohol.

Camellia sinensis was procured from Tea State of Tata Group of Company, TALAT, Assam, H.P. (India). Preparation of GTE was done according to the method described by [20]. Green tea is prepared by picking the leaves, lightly steaming them, and allowing them to dry. The dried material was ground into powder using mortar and pestle and sieved with a sieve. $100 \mathrm{~g}$ of the powdered plant material was steeped in $600 \mathrm{~mL}$ of distilled water and heated in water bath for $3 \mathrm{~h}$ at $90^{\circ} \mathrm{C}$. The mixture was allowed to cool to room temperature, filtered, and dried. Total $3 \mathrm{gm}$ of yield of dried GTE was obtained. This GTE was used to treat rats.

At the end of study, body weights of all animals were recorded, then sacrificed under light ether anesthesia, and dissected. The blood samples were collected by retroorbital plexus in fluoride and plain glass tubes. Liver was removed, weighed, and processed for biochemical studies. Blood samples from rats were immediately centrifuged at $3000 \mathrm{rpm}$ for $10 \mathrm{~min}$ at $4^{\circ} \mathrm{C}$ for serum samples. The supernatant of serum was separated from the pellet and used for biochemical analysis.

2.3. Histopathological Examination. After scarification of rats, the samples of liver tissues were collected from all groups. For histological study, they were fixed in $10 \%$ neutral buffered formalin, dehydrated in ascending grades of ethanol alcohols, cleared in xylol, casting, blocking, cutting at $5 \mu \mathrm{m}$ thickness, and stained [21]. For the homogenate, liver was removed quickly and kept in iced $0.15 \mathrm{M} \mathrm{NaCl}$ solution, for removing the blood cells, blotted on filter paper, weighed, and homogenized. The supernatant was kept on ice until assayed after centrifugation of homogenates at $10,000 \mathrm{~g}$ for $15 \mathrm{~min}$ at $4^{\circ} \mathrm{C}$.

\subsection{Biochemical Analysis}

2.4.1. Measurement of Blood Alcohol. Blood was taken from the tail vein $1 \mathrm{~h}$ after gavage, 2 weeks after initiation of alcohol. Blood alcohol levels (BAL) were measured using the alcohol dehydrogenase kit from Sigma Chemical Co., India [22].
2.4.2. Determination of Liver Enzymatic Markers. The levels of liver enzymes were measured using commercial kits (Sigma Chemical Co., India). The plasma levels of alanine transaminase (ALT) and aspartate transaminase (AST) were estimated according to [23] and alkaline phosphatase (ALP) was according to [24].

2.4.3. Determination of Liver Nonenzymatic Markers. The levels of cholesterol and triglycerides were measured by using standard assay kits (Sigma Chemical Co., India).

2.4.4. Determination of Total Proteins Levels. Estimation of total proteins levels in plasma and in liver tissue homogenates was measured by the method previously described using bovine serum albumin as the standard [25]. The plasma levels of albumin were determined using commercial kit (Sigma Chemical Co., India) according to Pinnell and Northam colorimetric method [26].

2.4.5. Determination of Liver MDA Contents. The tissues of liver were thawed, weighed, and homogenized $1: 9 \mathrm{w}: \mathrm{v}$ in $0.9 \%$ saline. Then the homogenates were centrifuged at $3000 \mathrm{rpm}$ for $10 \mathrm{~min}$ at $4^{\circ} \mathrm{C}$ in a high-speed centrifuge and the supernatant was taken for the assays of MDA (a measure of lipid peroxidation) contents. MDA was assayed by the measurement of thiobarbituric acid-reactive substances (TBARS) levels spectrophotometrically at $532 \mathrm{~nm}$. Results were expressed as nmol. $\mathrm{mg}^{-1}$ protein [27].

2.4.6. Determination of Antioxidants. The level of superoxide dismutase (SOD) in liver tissue homogenate was assayed according to [28]. Level of GST in liver homogenates was measured according to Habig et al. [29].

2.5. Statistical Analysis. The results were presented as mean \pm SD. Statistical significance and differences from control and test values were evaluated by Student's $t$-test. Statistical probability $P<0.05$ was considered as statistically significant. Statistical analysis was conducted by using Sigma Plot software (Version 11).

\section{Results}

3.1. Measurement of Blood Alcohol. The rats increased their weight at a constant rate in each of the groups studied; there was no difference in weight gain among the groups. At week 2 , BAL $1 \mathrm{~h}$ after ethanol administration by gavage was similar in alcohol/GTE group $(376.6 \pm 68.1 \mathrm{mg} / 100 \mathrm{~mL})$ and alcohol group $(387.3 \pm 51.9 \mathrm{mg} / 100 \mathrm{~mL})$.

3.2. GTE Effect on $\mathrm{C}_{2} \mathrm{H}_{5} \mathrm{OH}$ Induced Changes in Liver Enzymatic Markers. The levels of ALT, AST, and ALP were evaluated in albino rats serum. As shown in Tables 1 and 2, a single dose of $\mathrm{EtOH}(0.5 \mathrm{~mL} / 100 \mathrm{gm}$ body weight) caused hepatotoxicity. The levels of these enzymatic markers in ethanol control group were increased significantly as compared to control groups. These increased levels were due to the liver cell injuries induced by EtOH. Administration of GTE significantly prevented the EtOH-induced elevation of serum ALT, AST, and ALP levels. 
TABLE 1: Effect of AQGTE on concentrations of nonenzymatic biochemical parameters in blood in chronic ethanol-induced hepatic damage in rats.

\begin{tabular}{lcccc}
\hline Analyzed parameters & Controls & $\begin{array}{c}\text { EtOH group } \\
\mathbf{0 . 5} \mathbf{~ m L} / \mathbf{k g ~ B ~ w t . ~}\end{array}$ & $\begin{array}{c}\text { EtOH + GTE group } \\
\mathbf{0 . 5} \mathbf{~ m L}+\mathbf{5} \mathbf{~ m g} / \mathbf{k g ~ B ~ w t . ~}\end{array}$ & $\begin{array}{c}\text { EtOH + GTE group } \\
\mathbf{0 . 5} \mathbf{~ m L}+\mathbf{1 0} \mathbf{~ m g} / \mathbf{k g ~ B ~ w t .}\end{array}$ \\
\hline AST (IU/L) & $22.00 \pm 3.139$ & $46.50 \pm 2.715^{* * *}$ & $42.50 \pm 2.184^{* * * *}$ & $28.16 \pm 2.119^{* * *}$ \\
ALT (IU/L) & $39.00 \pm 2.678$ & $100.00 \pm 5.319^{* * *}$ & $54.83 \pm 4.148^{* * *}$ & $24.83 \pm 1.678^{* * *}$ \\
ALP (KA Units/100 mL) & $104.00 \pm 8.871$ & $144.00 \pm 3.551^{* * *}$ & $130.50 \pm 3.303^{* * *}$ & $105.83 \pm 4.548^{* * *}$ \\
\hline
\end{tabular}

Values represent mean \pm SEM; $n=6$; significance as per Student's $t$-test.

${ }^{*} P<0.01,{ }^{* *} P<0.005,{ }^{* * *} P<0.001,{ }^{* * * *}$ nonsignificant, ${ }^{* * * * *}$ no change.

TABLE 2: Effect of AQGTE on concentrations of nonenzymatic biochemical parameters in liver tissue in chronic ethanol-induced hepatic damage in rats.

\begin{tabular}{lcccc}
\hline Analyzed parameters & Controls & $\begin{array}{c}\text { EtOH group } \\
\mathbf{0 . 5} \mathbf{~ m L / k g ~ B ~ w t . ~}\end{array}$ & $\begin{array}{c}\text { EtOH + GTE group } \\
\mathbf{0 . 5} \mathbf{~ m L}+\mathbf{5 ~} \mathbf{~ m g} / \mathbf{k g ~ B ~ w t . ~}\end{array}$ & $\begin{array}{c}\text { EtOH + GTE group } \\
\mathbf{0 . 5} \mathbf{~ m L}+\mathbf{1 0} \mathbf{~ m g} / \mathbf{k g ~ B ~ w t . ~}\end{array}$ \\
\hline AST (IU/L) & $1458 \pm 119.5$ & $2564 \pm 116.42^{* * *}$ & $24150 \pm 111.20^{* * * *}$ & $2398 \pm 87.29^{* * *}$ \\
ALT (IU/L) & $2230 \pm 146.1$ & $2564 \pm 116.42^{* * *}$ & $2415 \pm 111.45^{* * *}$ & $2398 \pm 87.89^{* * *}$ \\
ALP (KA Units/100 mL) & $108.00 \pm 8.867$ & $136.16 \pm 1.490^{* * *}$ & $129.66 \pm 0.98$ & $124.01 \pm 1.06^{* * *}$ \\
\hline
\end{tabular}

Values represent mean \pm SEM; $n=6$; significance as per Student's $t$-test.

${ }^{*} P<0.01,{ }^{* *} P<0.005,{ }^{* * *} P<0.001,{ }^{* * * *}$ nonsignificant, ${ }^{* * * * *}$ no change.

TABLE 3: Effect of AQGTE on concentrations of nonenzymatic biochemical parameters in liver tissue in chronic ethanol-induced hepatic damage in rats.

\begin{tabular}{lcccc}
\hline Analyzed parameters & Controls & $\begin{array}{c}\text { EtOH group } \\
\mathbf{0 . 5} \mathbf{~ m L / k g ~ B ~ w t . ~}\end{array}$ & $\begin{array}{c}\text { EtOH + GTE group } \\
\mathbf{0 . 5} \mathbf{~ m L}+\mathbf{5 ~ m g / k g ~ B ~ w t . ~}\end{array}$ & $\begin{array}{c}\text { EtOH + GTE group } \\
\mathbf{0 . 5} \mathbf{~ m L}+\mathbf{1 0} \mathbf{~ m g} / \mathbf{k g ~ B ~ w t . ~}\end{array}$ \\
\hline Cholesterol (mg/dL) & $56.21 \pm 5.279$ & $76.54 \pm 2.364^{*}$ & $67.65 \pm 1.89^{* * * *}$ & $57.30 \pm 1.115^{* * *}$ \\
Triglycerides (U/L) & $4.70 \pm 0.218$ & $32.50 \pm 1.453^{* * *}$ & $21.26 \pm 0.459^{* * * *}$ & $6.03 \pm 0.490^{* * *}$ \\
Total protein (g/dL) & $4.06 \pm 0.816$ & $2.52 \pm 0.159^{* * *}$ & $3.55 \pm 0.216^{* * * *}$ & $3.91 \pm 0.131^{* * *}$ \\
Albumin g/dL & $2.7 \pm 0.196$ & $1.38 \pm 0.106^{* * *}$ & $1.88 \pm 0.217^{* * * *}$ & $2.07 \pm 0.216^{* * *}$ \\
Globulin g/dL & $1.38 \pm 0.186$ & $1.12 \pm 0.077^{* * * *}$ & $1.68 \pm 0.245^{* * * *}$ & $1.86 \pm 0.216^{* * * *}$ \\
Urea (mg/dL) & $22.01 \pm 1.261$ & $23.00 \pm 0.633^{* * * * *}$ & $24.00 \pm 1.63$ & $26.33 \pm 2.85$ \\
\hline
\end{tabular}

Values represent mean \pm SEM; $n=6$; significance as per Student's $t$-test.

${ }^{*} P<0.01,{ }^{* *} P<0.005,{ }^{* * *} P<0.001,{ }^{* * * *}$ nonsignificant, ${ }^{* * * * *}$ no change.

3.3. GTE Effect on $\mathrm{C}_{2} \mathrm{H}_{5} \mathrm{OH}$ Induced Changes in Liver Nonenzymatic Markers. The cholesterol and triglycerides level of untreated ethanol control group was significantly higher than the other experimental groups (Table 3 ). In contrast, the levels of cholesterol and triglycerides of the $5 \mathrm{mg} / \mathrm{kg}$ body weight of GTE with EtOH groups were significantly lower than the ethanol control group. Added to this, $10 \mathrm{mg} / \mathrm{kg}$ body weight of GTE with EtOH was able to reduce the level of these nonenzymatic markers to near the normal value, whereas the level of urea was normal till the duration of experiments.

3.4. Determination of Total Proteins Levels in Liver. The level of total proteins depends upon the addition of albumin and globulin levels. The level of albumin in ethanol group was significantly lower than the control group, whereas the globulin level was normal. The level of albumin in $5 \mathrm{mg} / \mathrm{kg}$ body weight of GTE with EtOH groups was significantly higher, whereas $10 \mathrm{mg} / \mathrm{kg}$ body weight dose of GTE was able to increase the level of albumin to near the normal value when compared with ethanol and control groups.

3.5. GTE Effect on $\mathrm{C}_{2} \mathrm{H}_{5} \mathrm{OH}$ Induced Changes in Liver MDA Contents. The level of MDA (Table 4) in ethanol control group was significantly increased as compared to control groups. The increased level of MDA in ethanol control group indicated the presence of lipid peroxidation of liver cells, which was due to the toxic effect of EtOH. Furthermore, all of the GTE treatment groups were significantly different as compared to ethanol control group, and the MDA content was normalized as compared to normal control and ethanol control groups. Both doses of GTE were able to reduce the level of MDA as compared to normal control.

3.6. GTE Effect on $\mathrm{C}_{2} \mathrm{H}_{5} \mathrm{OH}$ Induced Changes in Activity of Antioxidant Enzymes. Table 4 summarizes the activities of hepatic antioxidant enzymes. Chronic EtOH administration to rats caused a significant decrease in the activities of SOD and a significant increase in the level of GST. $5 \mathrm{mg}$ doses of GTE were able to increase the level of SOD and decrease the level of GST as compared to ethanol control. $10 \mathrm{mg}$ doses of GTE were able to normalize the levels of SOD and GST as compared to control groups and showed a spectacular restoration of hepatic SOD and GST activities.

3.7. Histopathological Examination. The liver sections from different experimental groups were used to observe 
TABLE 4: Effect of AQGTE on concentrations of MDA content and activity of antioxidant enzymes in liver tissue in chronic ethanol-induced hepatic damage in rats.

\begin{tabular}{|c|c|c|c|c|}
\hline Analyzed parameters & Controls & $\begin{array}{c}\text { EtOH group } \\
\mathbf{0 . 5} \text { mL/kg B wt. }\end{array}$ & $\begin{array}{c}\text { EtOH + GTE group } \\
\mathbf{0 . 5} \mathbf{~ m L}+\mathbf{5} \mathbf{~ m g} / \mathbf{k g ~ B ~ w t . ~}\end{array}$ & $\begin{array}{c}\text { EtOH + GTE group } \\
\mathbf{0 . 5} \mathbf{~ m L ~ + ~} \mathbf{1 0 ~} \mathbf{~ g /} / \mathbf{k g ~ B ~ w t} .\end{array}$ \\
\hline MDA (nmol/mg protein) $)^{1}$ & $4.20 \pm 0.068$ & $10.20 \pm 0.483^{* * *}$ & $6.00 \pm 0.266^{* * * *}$ & $3.90 \pm 0.085^{* * *}$ \\
\hline $\mathrm{SOD}(\mathrm{U} / \mathrm{mg} \text { protein })^{1}$ & $16.15 \pm 0.054$ & $11.44 \pm 0.168^{* * *}$ & $14.54 \pm 0.145^{* * * *}$ & $18.36 \pm 0.131^{* * *}$ \\
\hline GST $(\mu \mathrm{g} / \mathrm{min} / \mathrm{mg}$ protein $)$ & $3.23 \pm 0.154$ & $6.96 \pm 0.205^{* * *}$ & $4.20 \pm 0.169^{* * * *}$ & $3.46 \pm 0.023^{* * *}$ \\
\hline
\end{tabular}

Values represent mean \pm SEM; $n=6$; significance as per Student's $t$-test.

${ }^{*} P<0.01,{ }^{* *} P<0.005,{ }^{* * *} P<0.001,{ }^{* * * *}$ nonsignificant, ${ }^{* * * * *}$ no change.

${ }^{1}$ Number of nmol per 1 .

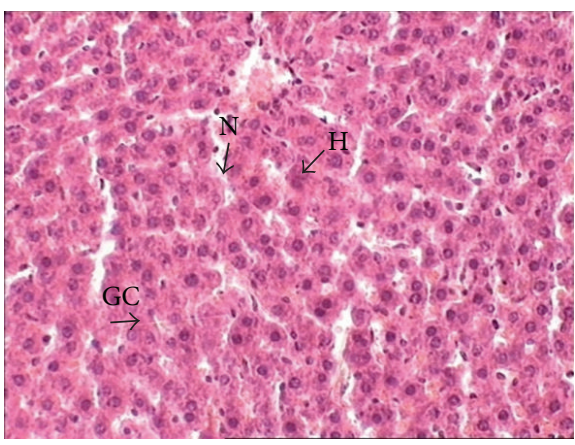

(a)

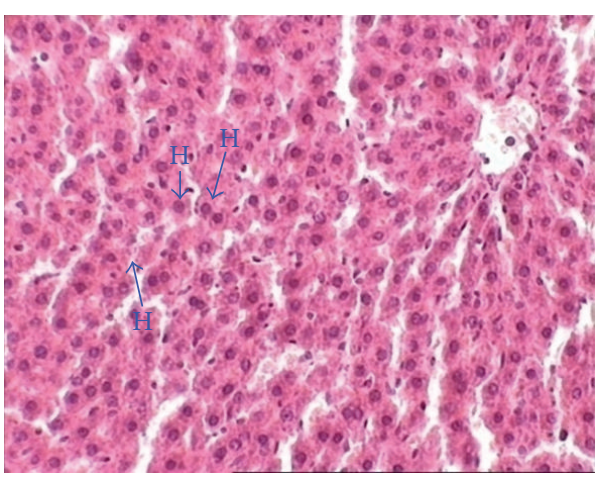

(c)

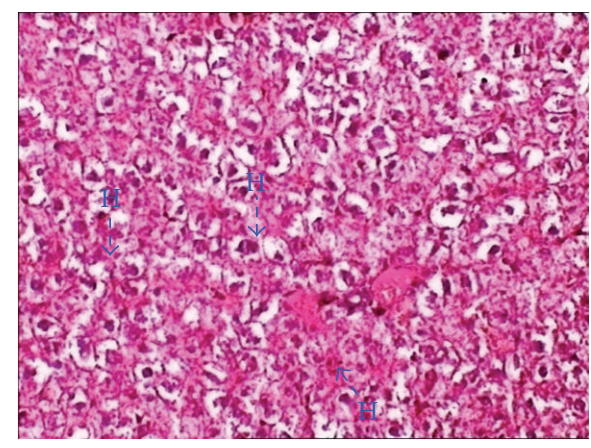

(b)

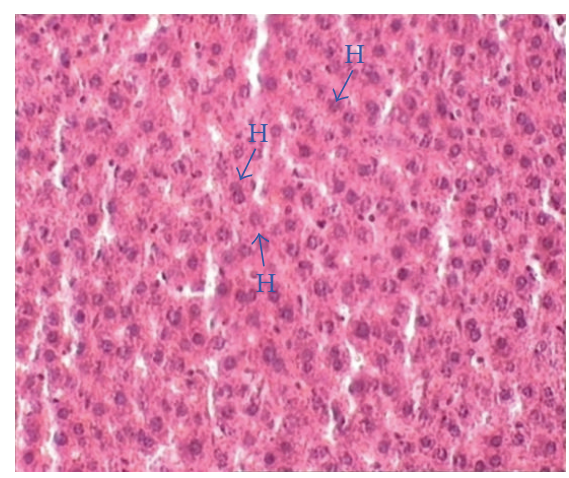

(d)

Figure 1: Microsection of liver of different experimental groups showing normal structure having hepatocytes $(\mathrm{H})$ with granular cytoplasm (GC), and clear nucleus (N) was stained with hematoxylin and eosin with the magnification of 400x. (a) Normal control with normal structure of liver cells. (b) Ethanol control with several microvacuolations of hepatocytes condition as indicated by the dashed line arrows. (c) $0.5 \mathrm{~mL}$ $\mathrm{EtOH}+5 \mathrm{mg} / 100 \mathrm{gm}$ AQGTE-treated group with recovery effect from microvacuolation of hepatocytes. (d) $0.5 \mathrm{~mL} \mathrm{EtOH}+10 \mathrm{mg} / 100 \mathrm{gm}$ AQGTE-treated group with recovery effect from microvacuolation of hepatocytes. $\mathrm{H}=$ hepatocyte, $\mathrm{S}=$ sinusoidal space, hepatocyte developed with microvacuolation.

histopathological changes which were stained with $\mathrm{H}$ and E staining and observed via a light microscope (Figure 1). In normal control group (Figure 1(a)), normal hepatocytes were observed, while, in ethanol control (Figure 1(b)), the hepatocytes showed fatty changes which were also known as microvesicular steatosis where the hepatocytes developed an open space around the nuclei. The administration of $5 \mathrm{mg} / \mathrm{kg}$ and $10 \mathrm{mg} / \mathrm{kg}$ body weight of GTE with EtOH showed a recovery effect of hepatocytes with minimal to no microvesicular steatosis. These results showed that GTE treatment resulted in a protective effect on $\mathrm{EtOH}$-induced hepatotoxicity.

\section{Discussion}

Ethanol is a hepatotoxicant to induce liver damage since it is clinically relevant [30]. This liver damage is associated with several reactions of free radicals such as reactive oxygen species (ROS) which causes elevation in MDA and GST content while reducing the level of SOD. The elevation and reduction of enzymatic and non-enzymatic markers of serum were also associated with this condition. Alcoholic liver disease was normally found in liver histology. GTE was enriched with antioxidants that could revert and lower the free radicals level. It had shown that the beneficial effects 
of this phytochemical in preventing the ethanol-induced hepatotoxicity are mediated by the antioxidant effects.

In the present study, we evaluated the protective effects of GTE against ethanol-induced hepatotoxicity. Ethanol administration increased the BAL, which caused the changes in the behavior of rats. Both doses of green tea extract normalized this change in BALs [22]. Ethanol administration elevated the concentrations of key cellular enzymes like AST, ALT, and ALP present in the liver cells leak into the serum during liver damage [31-35]. Elevated activities of these enzymes indicate hepatocytes damage where the leakage of cell membrane participated in the accumulation of these enzymes into the plasma [36, 37]. This is because of higher concentration of alcohol dehydrogenase in liver, which catalyzes alcohol to its corresponding aldehyde [38]. GTE had the ability to reduce the level of these enzyme markers. Therefore, prolonged treatment of $10 \mathrm{mg} / 100 \mathrm{gm}$ body weight of GTE administration could help to normalize the ALT, AST, and ALP enzyme levels. Our results are also consistent with protective effects of different extracts with antioxidant ability against alcohol-induced hepatocyte cells of liver [20, 35, 3941]. Ethanol administration decreased (serum protein and albumin) and increased (cholesterol and TG) the levels of nonenzymatic markers which caused the liver damage. This damage is attributed to the higher concentration of alcohol dehydrogenase enzyme which catalyses alcohol to aldehyde and accumulation of export type proteins due to inhibition of the secretion of the proteins from the liver of alcoholics $[38,42]$. Both doses of GTE restored the low level of protein in a dose dependent manner to normal level [43-45]. Level of cholesterol was increased with ethanol and decreased with both doses of GTE in all treatment groups [46].

Liver histology of such experimental animals also showed improvement (Figure 1). In this study these biochemical tests were supported by histopathological observations of liver sections [47].

The level of MDA and GST in cirrhotic rats was found to be high as compared to the controls $[48,49]$. The levels of MDA and GST content were low in GTE treated group (Table 4) as polyphenol rich green tea extracts inhibit lipid peroxidation in experimental rats [50]. During this study, the antioxidant system of cirrhotic rats was severely impaired, causing a high level of MDA and GST. The oxidative tissue damage in cirrhosis causes a significantly low level of catalase. During the process of inflammation, oxidative stress occurs which leads to a significant decrease in antioxidant enzyme system. The main target of oxidative stress is the poly unsaturated fatty acids in cell membranes causing lipid peroxidation and excessive formation of MDA and GST which may lead to damage of the cell structure and function [51]. The low level of SOD indicates that the high risks of cell injuries and the treatment of GTE doses tend to increase or normalize the level of SOD. The level of SOD in the liver of alcohol-induced mice treated with both doses of GTE was observed to be increased. In addition, this signified that GTE could provide the elevated SOD enzyme to the injured liver cells which in turn could recover the liver cells to normal and eventually be able to produce the significant amount of SOD enzyme by itself as a protective action from the damage caused by toxic substance such as alcohol [47]. Chronic alcohol consumption not only activates free radical generation, but also alters the levels of both enzymatic and nonenzymatic endogenous antioxidant systems [14].

\section{Conclusion}

In conclusion, in the present study, we investigated that the natural antioxidants present in AQGTE ameliorate liver damage caused by chronic ethanol exposure. These results were more effective in reverting the enzymatic markers (AST, ALT, and ALP), nonenzymatic markers in liver homogenate (protein, cholesterol, and triglycerides), antioxidant activity in liver homogenate (MDA, GST, and SOD), and histological conditions back to normal. It shows that GTE has the capability to prevent this toxicity by inhibiting the hepatocyte damage, peroxidation of lipids, and improving the activity of antioxidant enzymes.

\section{Conflict of Interests}

The authors declare that there is no conflict of interests regarding the publication of this paper.

\section{Acknowledgment}

The authors are grateful to the Director, Scientific and Applied Research Center, Meerut, U.P., India, for providing research facilities and encouragement to Poonam Rani or Lodhi.

\section{References}

[1] E. Cebral, A. Lasserre, V. Rettori, and M. A. F. De Gimeno, "Impaired mouse fertilization by low chronic alcohol treatment," Alcohol and Alcoholism, vol. 32, no. 5, pp. 563-572, 1997.

[2] C. Loguercio, P. Piscopo, C. Guerriero, V. De Girolamo, D. Disalvo, and C. Del Vecchio Blanco, "Effect of alcohol abuse and glutathione administration on the circulating levels of glutathione and on antipyrine metabolism in patients with alcoholic liver cirrhosis," Scandinavian Journal of Clinical and Laboratory Investigation, vol. 56, no. 5, pp. 441-447, 1996.

[3] J. K. Reddy and M. S. Rao, "Lipid metabolism and liver inflammation-II. Fatty liver disease and fatty acid oxidation," American Journal of Physiology. Gastrointestinal and Liver Physiology, vol. 290, no. 5, pp. G852-G858, 2006.

[4] M. G. Shalan, M. S. Mostafa, M. M. Hassouna, S. E. H. El-Nabi, and A. El-Refaie, "Amelioration of lead toxicity on rat liver with Vitamin C and silymarin supplements," Toxicology, vol. 206, no. 1, pp. 1-15, 2005.

[5] B. F. Hagen, A. Bjorneboe, G.-A. Bjorneboe, and C. A. Drevon, "Effect of chronic ethanol consumption on the content of $\alpha$ tocopherol in subcellular fractions of rat liver," Alcoholism: Clinical and Experimental Research, vol. 13, no. 2, pp. 246-251, 1989.

[6] O. H. Lowry, N. J. Rosebrough, A. L. Farr, and R. J. Randall, "Protein measurement with the Folin phenol reagent.," The Journal of biological chemistry, vol. 193, no. 1, pp. 265-275, 1951.

[7] S. A. Jewell, D. Di Monte, A. Gentile, A. Guglielmi, E. Altomare, and O. Albano, "Decreased hepatic glutathione in chronic 
alcoholic patients," Journal of Hepatology, vol. 3, no. 1, pp. 1-6, 1986.

[8] S. Sherlock and J. Dooley, Assessment of Liver Function in Diseases of the Liver and Biliary System, Blackwell Scientific Publications, Oxford, UK, 1993.

[9] P. E. Hartman and D. W. Shankel, "Antimutagens and Anticarcinogens a survey of putative interceptor molecules," Environmental and Molecular Mutagenesis, vol. 15, no. 3, pp. 145-182, 1990.

[10] S. Kato, T. Kawase, J. Alderman, N. Inatomi, and C. S. Lieber, "Role of xanthine oxidase in ethanol-induced lipid peroxidation in rats," Gastroenterology, vol. 98, no. 1, pp. 203-210, 1990.

[11] S. M. Khan and G. Kour, "Subacute oral toxicity of chlorpyriphos and protective effect of green tea extract," Pesticide Biochemistry and Physiology, vol. 89, no. 2, pp. 118-123, 2007.

[12] S. Tokumaru, I. Tsukamoto, H. Iguchi, and S. Kojo, "Specific and sensitive determination of lipid hydroperoxides with chemical derivatization into 1-naphthyldiphenylphosphine oxide and high-performance liquid chromatography," Analytica Chimica Acta, vol. 307, no. 1, pp. 97-102, 1995.

[13] L. Tussey and M. R. Felder, "Tissue-specific genetic variation in the level of mouse alcohol dehydrogenase is controlled transcriptionally in kidney and posttranscriptionally in liver," Proceedings of the National Academy of Sciences of the United States of America, vol. 86, no. 15, pp. 5903-5907, 1989.

[14] E. Albano, S. French, and M. Ingelman-Sundberg, "Cytochrome p450 2E1, hydroxyl ethyl radicals, and immune reaction associated alcoholic liver injury," Alcoholism: Clinical and Experimental Research, vol. 18, pp. 1057-1068, 1994.

[15] S. M. K. R. Zaidi, T. M. Al-Qirim, and N. Banu, "Effects of antioxidant vitamins on glutathione depletion and lipid peroxidation induced by restraint stress in the rat liver," Drugs in R \& D, vol. 6, no. 3, pp. 157-165, 2005.

[16] J. King, "The transferase alanine and aspartate transaminase," in Practical Clinical Enzymology, pp. 363-395, Nostrand, London, UK, 1965.

[17] S. S. Bun, H. Bun, D. Guédon, C. Rosier, and E. Ollivier, "Effect of green tea extracts on liver functions in Wistar rats," Food and Chemical Toxicology, vol. 44, no. 7, pp. 1108-1113, 2006.

[18] Y. Cai, L. Ma, L. Hou, B. Zhou, L. Yang, and Z. Liu, "Antioxidant effects of green tea polyphenols on free radical initiated peroxidation of rat liver microsomes," Chemistry and Physics of Lipids, vol. 120, no. 1-2, pp. 109-117, 2002.

[19] X. Jin, R.-H. Zheng, and Y.-M. Li, "Green tea consumption and liver disease: a systematic review," Liver International, vol. 28, no. 7, pp. 990-996, 2008.

[20] D. Dahiru and O. Obidoa, "Pretreatment of albino rats with aqueous leaf extract of Ziziphus mauritiana protects against alcohol induced liver damage," Tropical Journal of Pharmaceutical Research, vol. 6, no. 2, article 705, 2007.

[21] J. D. Bancroft, Histopathological Stains and their Diagnostic Uses, Churchill Livingstone, New York, NY, USA, 1975.

[22] B. M. Walker and C. L. Ehlers, "Age-related differences in the blood alcohol levels of Wistar rats," Pharmacology Biochemistry and Behavior, vol. 91, no. 4, pp. 560-565, 2009.

[23] H. Kuper, A. Tzonou, E. Kaklamani, C. C. Hsieh, P. Lagiou, and H. O. Adami, "Tobacco smoking, alcohol consumption and their interaction in the causation of hepatocellular carcinoma," International Journal of Cancer, vol. 85, pp. 498-502, 2000.

[24] G. N. Bowers Jr. and R. B. McComb, "A continuous spectrophotometric method for measuring the activity of serum alkaline phosphatase," Clinical Chemistry, vol. 12, no. 2, pp. 70-89, 1966.
[25] L. A. Menahan, K. A. Sobocinski, and B. P. Austin, "The origin of plasma alkaline phosphatase activity in mice and rats," Comparative Biochemistry and Physiology B: Comparative Biochemistry, vol. 79, no. 2, pp. 279-283, 1984.

[26] R. Polavarapu, D. R. Spitz, J. E. Sim et al., "Increased lipid peroxidation and impaired antioxidant enzyme function is associated with pathological liver injury in experimental alcoholic liver disease in rats fed diets high in corn oil and fish oil," Hepatology, vol. 27, no. 5, pp. 1317-1323, 1998.

[27] A. E. Pinnell and B. E. Northam, "New automated dye-binding method for serum albumin determination with bromcresol purple," Clinical Chemistry, vol. 24, no. 1, pp. 80-86, 1978.

[28] P. E. Molina, C. McClain, D. Valla et al., "Molecular pathology and clinical aspects of alcohol-induced tissue injury," Alcoholism: Clinical and Experimental Research, vol. 26, no. 1, pp. 120-128, 2002.

[29] W. H. Habig, M. J. Pabst, and W. B. Jakoby, "Glutathione $S$ transferases. The first enzymatic step in mercapturic acid formation," Journal of Biological Chemistry, vol. 249, no. 22, pp. 7130-7139, 1974.

[30] C. S. Lieber, "Role of oxidative stress and antioxidant therapy in alcoholic and nonalcoholic liver diseases," Advances in Pharmacology, vol. 38, pp. 601-628, 1997.

[31] A. Raj, K. V. Praveen, S. Varghese, J. K. Mukkadan, and P. K. Joseph, "Biochemical effects of feeding soft drink and ethanol," Indian Journal of Experimental Biology, vol. 47, no. 5, pp. 333337, 2009.

[32] S. K. Das, L. Dhanya, S. Varadhan, S. Mukherjee, and D. M. Vasudevan, "Effects of chronic ethanol consumption in blood: a time dependent study on rat," Indian Journal of Clinical Biochemistry, vol. 24, no. 3, pp. 301-306, 2009.

[33] A. C. Deb, Fundamentals of Biochemistry, New Central Book Agency, Kolkata, India, 7th edition, 1998.

[34] V. Gujrati, N. Patel, V. N. Rao et al., "Hepatoprotective activity of alcoholic and aqueous extracts of leaves of Tylophora indica (Linn.) in rats," Indian Journal of Pharmacology, vol. 39, no. 1, pp. 43-47, 2007.

[35] A. Y. Sun, M. Ingelman-Sundberg, E. Neve et al., "Ethanol and oxidative stress," Alcoholism: Clinical and Experimental Research, vol. 25, no. 5, pp. 237-237, 2001.

[36] E. Baldi, P. Burra, M. Plebani, and M. Salvagnini, "Serum malondialdehyde and mitochondrial aspartate aminotransferase activity as markers of chronic alcohol intake and alcoholic liver disease," The Italian Journal of Gastroenterology, vol. 25, no. 8, pp. 429-432, 1993.

[37] N. J. Schisler and S. M. Singh, "Effect of ethanol in vivo on enzymes which detoxify oxygen free radicals," Free Radical Biology and Medicine, vol. 7, no. 2, pp. 117-123, 1989.

[38] C. S. Yang, J. M. Landau, M. T. Huang, and H. L. Newmark, "Inhibition of carcinogenesis by dietary polyphenolic compounds," Annual Review of Nutrition, vol. 21, pp. 381-406, 2001.

[39] B. Halliwell and J. M. C. Gutteridge, "Oxygen free radicals and iron in relation to biology and medicine: some problems and concepts," Archives of Biochemistry and Biophysics, vol. 246, no. 2, pp. 501-514, 1986.

[40] R. Nordmann, C. Ribière, and H. Rouach, "Implication of free radical mechanisms in ethanol-induced cellular injury," Free Radical Biology and Medicine, vol. 12, no. 3, pp. 219-240, 1992.

[41] H. Ohkawa, N. Ohishi, and K. Yagi, "Assay for lipid peroxides in animal tissues by thiobarbituric acid reaction," Analytical Biochemistry, vol. 95, no. 2, pp. 351-358, 1979. 
[42] E. Baraona and C. S. Lieber, "Effects of alcohol on hepatic transport of proteins," Annual Review of Medicine, vol. 33, pp. 281-292, 1982.

[43] H. P. Misra and I. Fridovich, "The role of superoxide anion in the autoxidation of epinephrine and a simple assay for superoxide dismutase.," The Journal of Biological Chemistry, vol. 247, no. 10, pp. 3170-3175, 1972.

[44] R. Nordmann, "Alcohol and antioxidant systems", Alcohol and Alcoholism, vol. 29, no. 5, pp. 513-522, 1994.

[45] S. Shaw, E. Jayatilleke, W. A. Ross, E. R. Gordon, and C. S. Leiber, "Ethanol-induced lipid peroxidation: potentiation by long-term alcohol feeding and attenuation by methionine," Journal of Laboratory and Clinical Medicine, vol. 98, no. 3, pp. 417-424, 1981.

[46] V. Arulmozhi, M. Krishnaveni, K. Karthishwaran, G. Dhamodharan, and S. Mirunalini, "Antioxidant and antihyperlipidemic effect of Solanum nigrum fruit extract on the experimental model against chronic ethanol toxicity," Pharmacognosy Magazine, vol. 6, no. 21, pp. 42-50, 2010.

[47] R. Saravanan, P. Viswanathan, and K. V. Pugalendi, "Protective effect of ursolic acid on ethanol-mediated experimental liver damage in rats," Life Sciences, vol. 78, no. 7, pp. 713-718, 2006.

[48] K. Husain, M. Vasquez Ortiz, and J. Lalla, "Physical training ameliorates chronic alcohol-induced hypertension and aortic reactivity in rat," Alcohol and Alcoholism, vol. 41, no. 3, pp. 247253, 2006.

[49] M. Saoudi, S. Jebahi, K. Jamoussi, G. B. Salah, C. Kallel, and A. El Fek, "Haematological and biochemical toxicity induced by methanol in rats: ameliorative effects of Opuntia vulgaris fruit extract," Human \& Experimental Toxicology, vol. 30, no. 12, pp. 1963-1971, 2011.

[50] Z. Zhou, X. Sun, and J. Y. Kang, "Metallothionein protection against alcoholic liver injury through inhibition of oxidative stress," Experimental Biology and Medicine, vol. 227, no. 3, pp. 214-222, 2002.

[51] M. A. Leo, M. Arai, M. Sato, and C. S. Lieber, "Hepatotoxicity of vitamin A and ethanol in the rat," Gastroenterology, vol. 82, no. 2, pp. 194-205, 1982. 


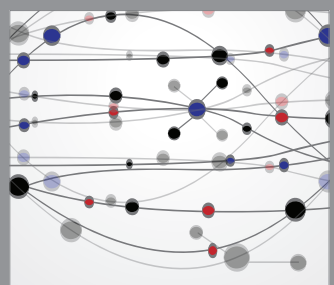

The Scientific World Journal
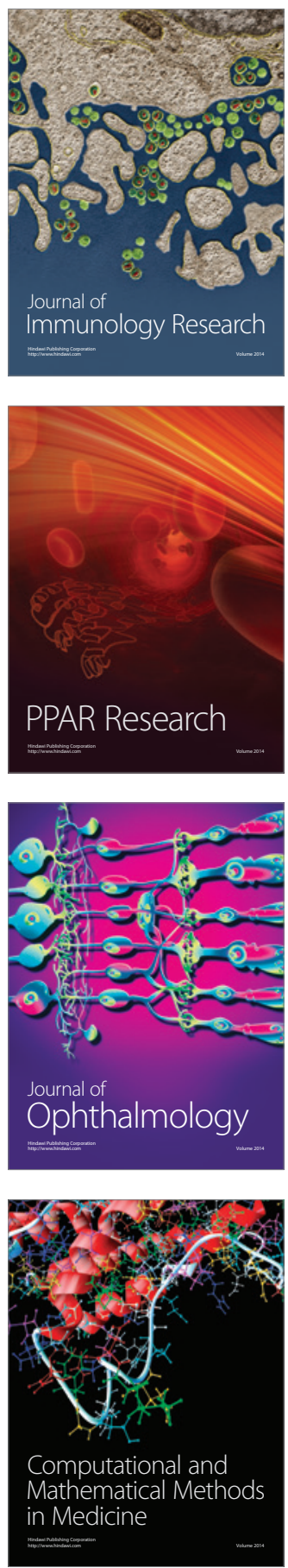

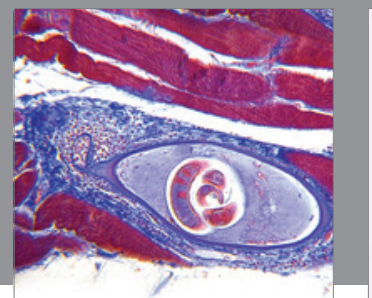

Gastroenterology

Research and Practice
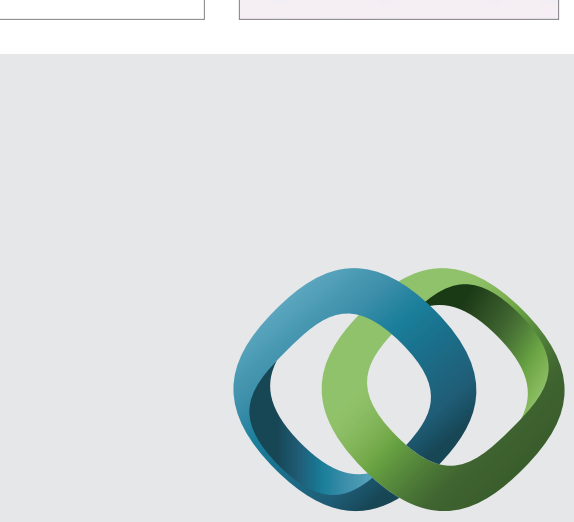

\section{Hindawi}

Submit your manuscripts at

http://www.hindawi.com
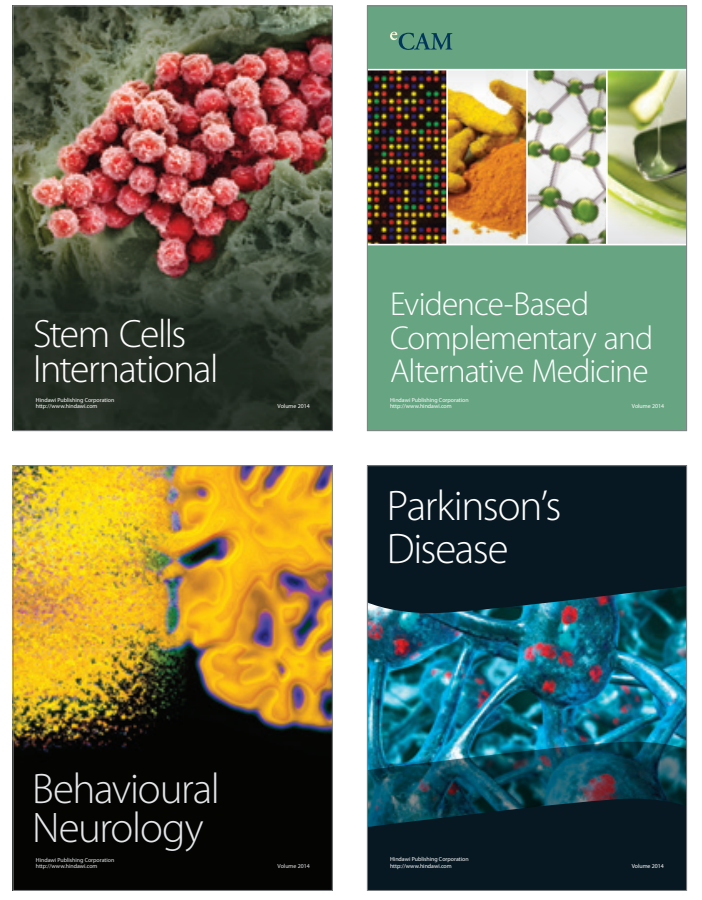
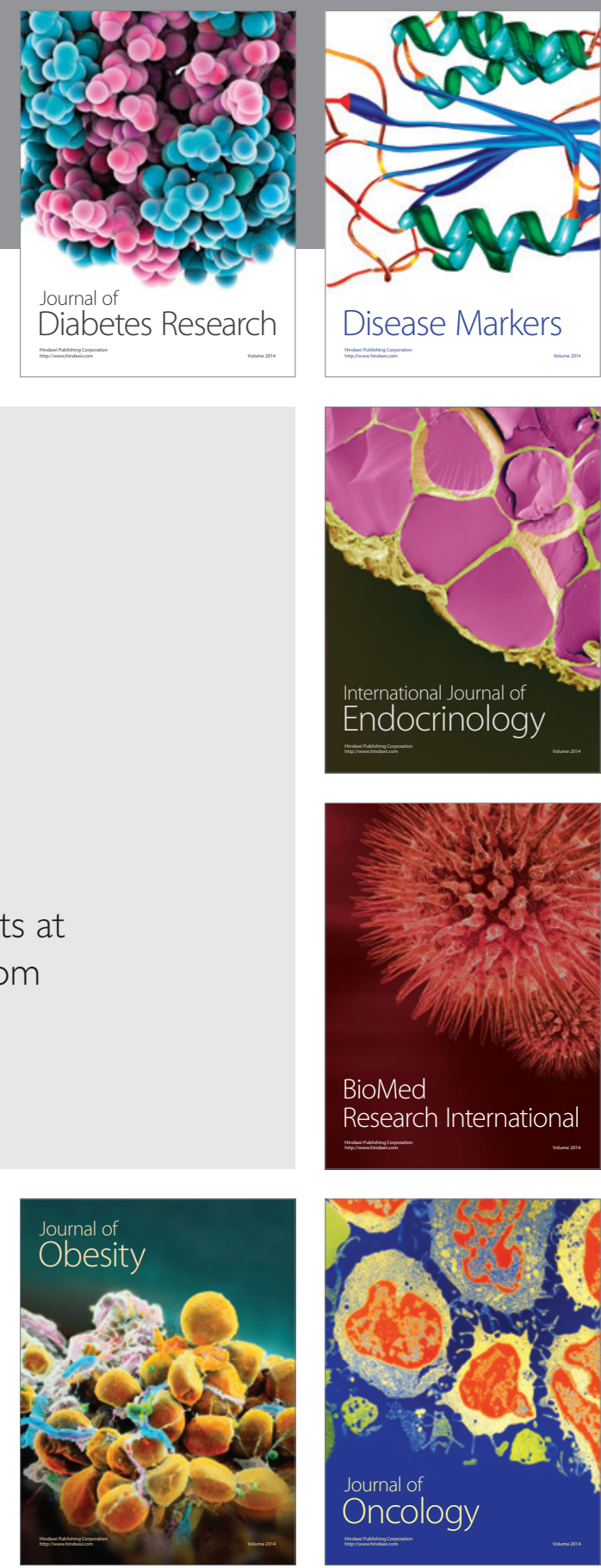

Disease Markers
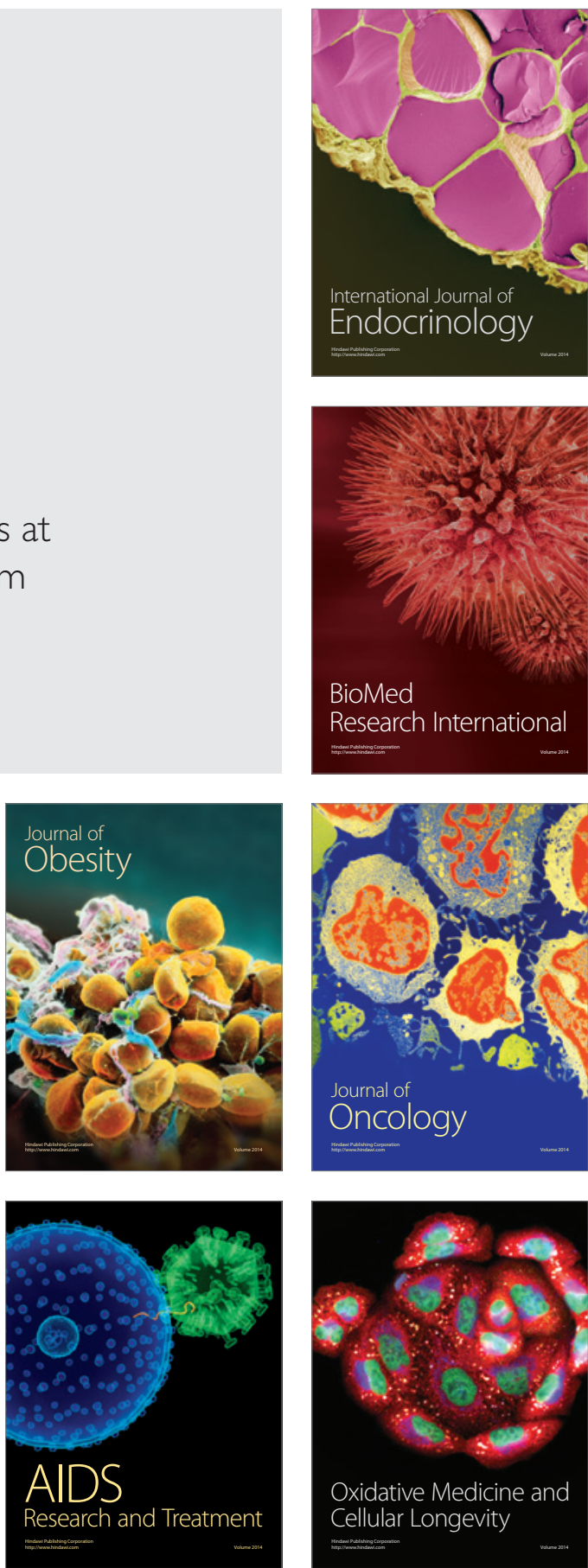